Jurnal Laut Khatulistiwa, Vol. 4 No. 1 (Febuari, 2021), Hal. 1-9.

\title{
Keanekaragaman Jenis Kepiting Bakau (Scylla Sp.) Di Kuala Kota Singkawang Kalimantan Barat
}

\section{Diversity Of Mud Crabs (Scylla Sp.) In Kuala Singkawang City, West Kalimantan}

\author{
Kwirinus Rio Kusuma1, Ikha Safitri ${ }^{2 *}$, Warsidah ${ }^{1}$ \\ ${ }^{1}$ Laboratorium Ilmu Kelautan, FMIPA Universitas Tanjungpura, Pontianak, Indonesia \\ *E-mail : isafitri@marine.untan.ac.id
}

Received : 10 Febuari 2021; Accepted: 23 Febuari 2021

Published: 28 February (C) Author(s) 2021. This article is open access

\begin{abstract}
Mangrove forests are the tropical coastal ecosystem that plays an important role as habitat, feeding ground, spawning ground, and nursery ground for various types of aquatic organisms, such as fish, mollusks, and crustaceans, including crabs. Mud crabs (Scylla sp.) found to be abundance in mangrove ecosystems as a key species. The mangrove ecosystem and environment condition influence the abudance of mud crabs. This study were aimed to determine the abundance and distribution of mud crabs and the condition of physico-chemical parameters in mangrove ecosystem Kuala Singkawang, West Kalimantan. The selection of sampling location using purposive sampling method with consideration of different enviromental characteristics. Sampling was carried out at three stations using quadrat transect $10 \times 10 \mathrm{~m}$, and the distance between plots was $50 \mathrm{~m}$. The results showed that the mud crabs found in the mangrove ecosystem of Kuala Kota Singkawang consisted of 2 species, namely Scylla serrata and S. olivacea with an abundance of 0.09 ind $/ \mathrm{m} 2$ and 0.02 ind $/ \mathrm{m} 2$, respectively. Mud crabs have a low diversity index $(0,47)$, high uniformity $(0,68)$, and moderate dominance index $(0,70)$. The physico-chemical water parameters in the mangrove area of Kuala Kota Singkawang were Optimal for supporting the life of mud crabs.
\end{abstract}

Keywords: diversity, distribution, mud crabs, Scylla sp.

Kwirinus R. Kusuma and Ikha Safitri contributed equally to this work

\begin{abstract}
Abstrak
Hutan mangrove merupakan ekosistem pesisir yang memiliki peran penting sebagai habitat, tempat mencari makan, pemijahan, dan pembesaran berbagai jenis organisme akuatik, seperti ikan, moluska, dan crustacea, termasuk kepiting. Kepiting bakau (Scylla sp.) ditemukan melimpah di ekosistem mangrove sebagai spesies kunci. Kelimpahan kepiting bakau dipengaruhi oleh kondisi ekosistem mangrove dan kondisi lingkungan. Tujuan penelitian ini untuk mengetahui kelimpahan dan distribusi kepiting bakau serta parameter fisika-kimia lingkungan yang mempengaruhi kehidupannya. Pemilihan lokasi pengambilan sampel menggunakan metode purposive sampling berdasarkan rona lingkungan yang berbeda. Pengambilan sampel dilakukan di 3 stasiun dengan petak contoh berukuran 10x10 m dan jarak antar plot $50 \mathrm{~m}$. Hasil penelitian menunjukkan bahwa kepiting bakau yang ditemukan di ekosistem mangrove Kuala Kota Singkawang Kalimantan Barat terdiri dari 2 spesies, yaitu Scylla serrata dan S. olivacea dengan kelimpahan 0,09 ind $/ \mathrm{m}^{2}$ dan 0,02 ind $/ \mathrm{m}^{2}$. Kepiting bakau memiliki indeks keanekaragaman rendah $(0,47)$, keseragaman tinggi $(0,68)$, dan dominansi sedang $(0,70)$. Faktor fisikakimia perairan di Kawasan mangrove Kuala Kota Singkawang masuk dalam rentang optimal yang dapat mempengaruhi keberadaan dan kelimpahan kepiting bakau.
\end{abstract}

Kata kunci : keanekaragaman, mangrove, Singkawang, Scylla serrata, Scylla olivacea

Kwirinus R. Kusuma dan Ikha Safitri memiliki kontribusi yang sama pada penelitian ini 
Jurnal Laut Khatulistiwa, Vol. 4. No. 1 (Febuari, 2021), Hal. 7-9.

\section{Pendahuluan}

Kota Singkawang merupakan salah satu wilayah pesisir di Kalimantan Barat yang memiliki hutan mangrove (BPS Kota Singkawang, 2016) khususnya di Kelurahan Kuala, Kecamatan Singkawang Barat. Ekosistem mangrove memiliki peran penting sebagai habitat, feeding ground, spawning ground, dan nursery ground berbagai jenis organisme akuatik (Rangkuti et al., 2017) seperti ikan, moluska, dan crustacea (Nagelkerken et al., 2008), termasuk kepiting.

Kepiting bakau (Scylla sp.) ditemukan melimpah di daerah pantai dengan vegetasi mangrove (Chairunnisa, 2004). Spesies ini diketahui sebagai spesies kunci (keystone species) (Ashton et al., 2003) yang berperan penting pada karakteristik sedimen serta kandungan bahan organik yang ada (Widyastuti, 2016). Kelimpahan kepiting bakau dipengaruhi oleh kondisi ekosistem mangrove. Tingkat kerapatan mangrove yang tinggi dapat menyediakan jumlah makanan yang cukup (Gita et al., 2015). Selain itu, parameter fisika-kimia lingkungan seperti suhu, salinitas, pH (Rizaldi et al., 2015), dan jenis substrat (Chairunnisa, 2004; Riniatsih dan Kushartono, 2009; Avianto et al., 2013) juga akan mempengaruhi keberadaan dan kelimpahan kepiting bakau.
Pemanfaatan hutan mangrove yang kurang memperhatikan lingkungan seperti alih fungsi lahan menjadi tambak, pemukiman, industri, dan lokasi wisata dapat mempengaruhi keseimbangan ekosistem dan menyebabkan degradasi habitat (Macintosh et al., 2002). Hal ini juga akan berdampak pada keberadaan dan kelimpahan biota termasuk kepiting bakau yang hidup di perairan tersebut.

Keanekaragaman kepiting bakau dan kondisi lingkungan perairan di Kuala Kota Singkawang belum pernah dikaji sebelumnya. Selain itu, adanya pemanfaatan hutan mangrove sebagai lokasi wisata dapat memberikan pengaruh pada lingkungan yang ada. Oleh karena itu, penelitian ini bertujuan untuk mengetahui kelimpahan dan distribusi kepiting bakau serta kondisi parameter fisikakimia lingkungan.

\section{Metodologi Penelitian \\ 2.1 Waktu dan Lokasi Penelitian}

Penelitian dilakukan pada Februari-Maret 2020 di Kawasan Hutan Mangrove Kuala Kota Singkawang, Kalimantan Barat. Penentuan lokasi pengamatan dilakukan dengan metode purposive sampling pada rona lingkungan yang berbeda. Stasiun I berada jauh dari aktivitas manusia $\left(00^{\circ} 55.319^{\prime} \mathrm{N} 108^{\circ} 57.666^{\prime} \mathrm{E}\right)$, stasiun II berada dekat dengan dengan pembangunan ekowisata $\left(00^{\circ} 55.365^{\prime} \mathrm{N} 108^{\circ} 57.715^{\prime} \mathrm{E}\right)$, dan

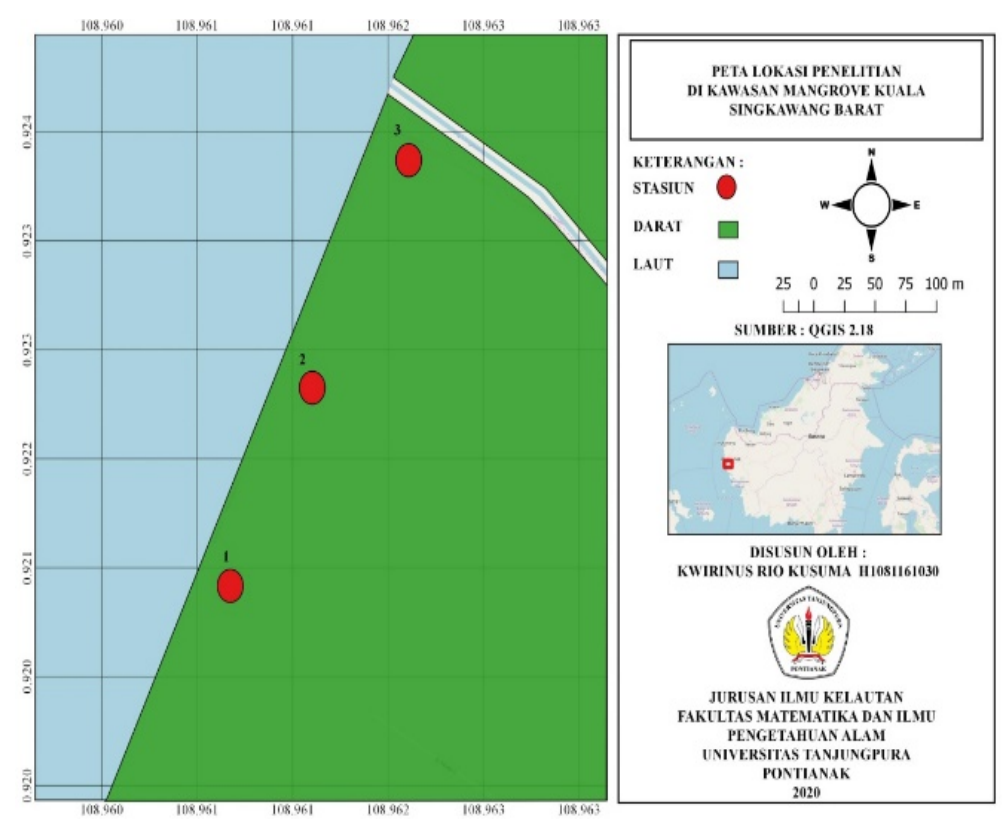

Gambar 1. Lokasi Penelitian 
Jurnal Laut Khatulistiwa, Vol. 4. No. 1 (Febuari, 2021), Hal. 7-9.

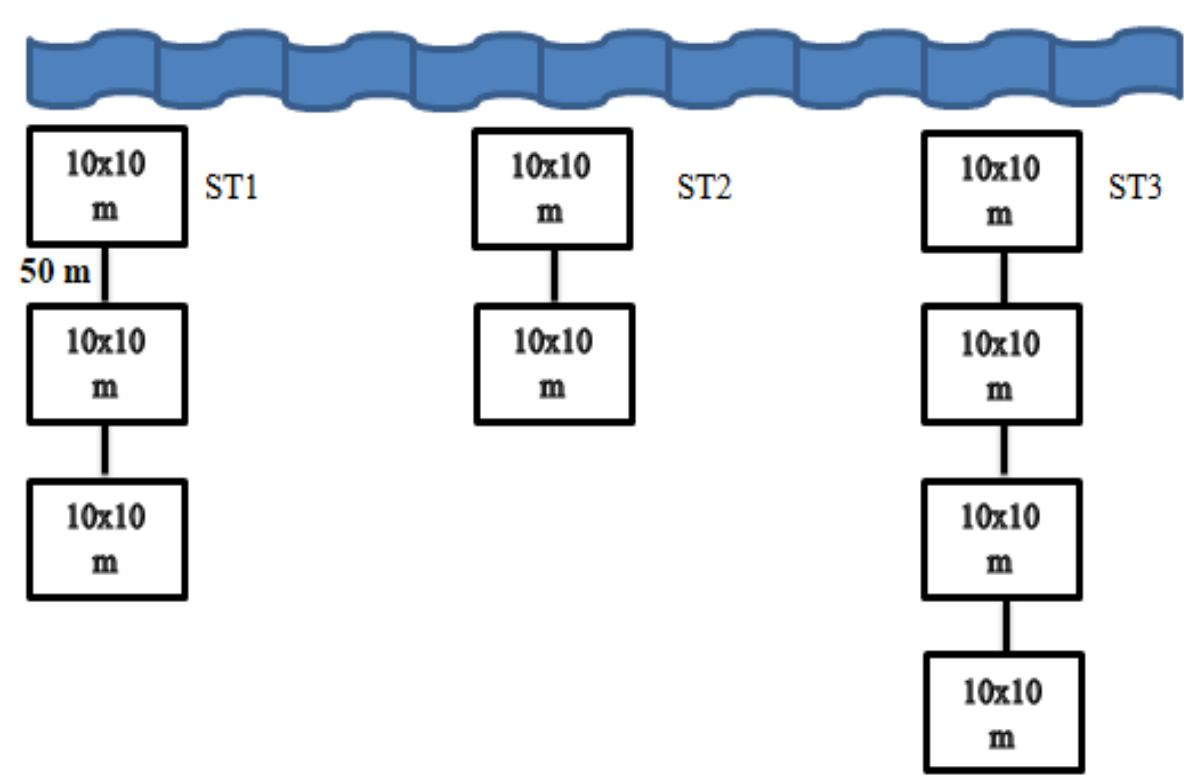

Gambar 2. Stasiun pengambilan sampel kepiting bakau (Scylla sp.)

stasiun III dekat dengan muara sungai $\left(00^{\circ} 55.412^{\prime} \mathrm{N} 108^{\circ} 57.738^{\prime} \mathrm{E}\right)$ (Gambar 1$)$.

\subsection{Pengamatan kepiting bakau (Scylla sp.)}

Pengamatan kepiting bakau dilakukan pada malam hari secara in situ di setiap stasiun. Sebuah garis transek ditarik tegak lurus garis pantai, dimulai dari vegetasi terakhir yang berada di tepi pantai. Setiap transek terdapat plot petak kuadrat berukuran 10x10 m dengan jarak antar plot adalah $50 \mathrm{~m}$. Panjang transek stasiun I adalah $130 \mathrm{~m}$ dan terdiri dari 3 plot, stasiun II sepanjang $80 \mathrm{~m}$ terdiri dari 2 plot, dan stasiun III sepanjang $300 \mathrm{~m}$ dengan 4 plot (Gambar 2). Hal ini dilakukan dengan mempertimbangkan keterwakilan wilayah tutupan mangrove yang ada di Kuala Kota Singkawang.

Pengamatan kepiting bakau dilakukan pada malam hari secara in situ di setiap stasiun. Sebuah garis transek ditarik tegak lurus garis pantai, dimulai dari vegetasi terakhir yang berada di tepi pantai. Setiap transek terdapat plot petak kuadrat berukuran 10x10 m dengan jarak antar plot adalah $50 \mathrm{~m}$. Panjang transek stasiun I adalah $130 \mathrm{~m}$ dan terdiri dari 3 plot, stasiun II sepanjang $80 \mathrm{~m}$ terdiri dari 2 plot, dan stasiun III sepanjang $300 \mathrm{~m}$ dengan 4 plot (Gambar 2). Hal ini dilakukan dengan mempertimbangkan keterwakilan wilayah tutupan mangrove yang ada di Kuala Kota Singkawang.

\subsection{Pengukuran parameter fisika-kimia lingkungan \\ Pengukuran parameter fisika-kimia} perairan seperti suhu, salinitas, $\mathrm{pH}$, dan DO (Dissolved Oxygen) dilakukan secara in situ menggunakan Water Quality Checker (WQC) instrument AZ8603, dan pasang surut menggunakan palang pasut. Sampel substrat diambil di setiap plot pada masing-masing stasiun kemudian dianalisis menggunakan metode ayakan basah di Laboratorium Mekanika Tanah, Fakultas Teknik, Universitas Tanjungpura, Pontianak. Pengukuran dilakukan di setiap plot pengambilan sampel dengan tiga kali ulangan.

\subsection{Analisis Data}

Data kelimpahan kepiting bakau dianalisis menggunakan rumus (Odum, 1993) :

Keterangan :

$$
K=\frac{\sum n i}{\mathrm{~A}}
$$

$\mathrm{K} \quad$ : kelimpahan kepiting bakau (ind $/ \mathrm{m}^{2}$ )

$\sum$ ni : jumlah individu spesies ke-i (ind)

A : luas daerah pengambilan sampel $\left(\mathrm{m}^{2}\right)$

Indeks keanekaragaman $\left(\mathrm{H}^{\prime}\right)$ ShanonWiener dihitung menggunakan rumus sebagai berikut (Odum, 1993) :

$$
H^{\prime}=-\sum p i \ln p i
$$


Jurnal Laut Khatulistiwa, Vol. 4. No. 1 (Febuari, 2021), Hal. 7-9.

Tabel 1. Kategori indeks keanekaragaman

\begin{tabular}{cc}
\hline Nilai & Kategori \\
\hline $\mathrm{H}^{\prime}<1$ & keanekaragaman rendah \\
$1<\mathrm{H}^{\prime}<3$ & keanekaragaman sedang \\
$\mathrm{H}^{\prime}>3$ & keanekaragaman tinggi \\
\hline
\end{tabular}

Tabel 2. Kategori indeks keseragaman

\begin{tabular}{cl}
\hline Nilai & \multicolumn{1}{c}{ Kategori } \\
\hline $\mathrm{C}<0.50$ & Dominansi rendah \\
$0,50<\mathrm{C}<0,75$ & Dominansi sedang \\
$\mathrm{C}>0,75$ & Dominansi tinggi \\
\hline
\end{tabular}

Keterangan :

$\mathrm{H}^{\prime} \quad$ : indeks keanekaragaman

pi : perbandingan jumlah individu suatu

jenis dengan keseluruhan jenis (ni/N)

ni : jumlah individu spesies ke-i

$\mathrm{N} \quad$ : jumlah total individu

Indeks keseragaman (E) dihitung menggunakan rumus sebagai berikut (Odum, 1993) :

Keterangan :

$$
\mathrm{E}=\frac{\mathrm{H}^{\prime}}{\ln S}
$$

$\mathrm{H}^{\prime}$ : indeks keanekaragaman

S : jumlah spesies yang ditemukan

$\mathrm{E}$ : indeks keseragaman

Indeks keseragaman berkisar antara 0-1, nilai $\mathrm{E}$ mendekati 0 maka sebaran individu antar jenis tidak seragam dan terjadi dominansi suatu jenis dan apabila nilai E mendekati 1 maka sebaran individu antar jenis seragam.

Indeks dominansi (C) dihitung menggunakan rumus sebagai berikut (Odum, 1993) :

Keterangan :

$$
\mathrm{C}=\sum\left(\frac{n i}{N}\right)^{2}
$$

C : indeks dominansi

ni : jumlah individu spesies ke-i

$\mathrm{N} \quad$ : jumlah total individu
Persentase ukuran partikel sedimen yang sebelumnya diayak, selanjutnya ditentukan jenisnya menggunakan metode Pyramid Soil Clasification USDA yang menggolongkan jenis substrat berdasarkan perbandingan pasir, lanau, dan lempung. Segitiga millar merupakan acuan yang digunakan dalam menentukan jenis substrat (Brower dan Zar, 1989).

\section{Hasil dan Pembahasan}

\subsection{Komposisi jenis kepiting bakau}

Komposisi jenis kepiting bakau yang ditemukan di kawasan hutan mangrove Kuala Kota Singkawang terdiri dari 2 spesies yaitu Scylla serrata dan S. olivacea (Gambar 3) dengan jumlah yang berbeda di masing-masing stasiun (Tabel 3). Berdasarkan hasil pengamatan, $S$. serrata yang ditemukan memiliki morfologi karapas berwarna hitam kecokelatan, lebar karapas berkisar 8-9,3 cm, capit berwarna cokelat kemerahan, dan pada bagian frontal terdapat 4 spina yang tajam. Sedangkan $S$. olivacea memiliki morfologi karapas berwarna cokelat kehijauan, lebar karapas berkisar 7-8 cm, capit berwarna hijau orange, dan bagian frontal terdapat spina bulat.

Berdasarkan hasil penelitian serupa di kawasan rehabilitasi mangrove Setapuk Kota Singkawang juga menemukan 2 spesies yang sama (Yulianti, 2018), sedangkan penelitian di KPH Batu Ampar Pontianak menemukan spesies $S$. serrata dan $S$. transquebarica 


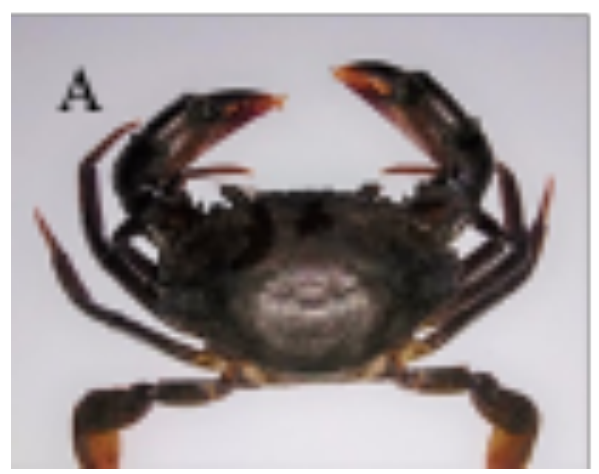

Gambar 3. Kepiting bakau yang ditemukan (A) S. serrata (B) S. olivacea di Kuala Kota Singkawang (Doc. Pribadi, 2020)

(Chairunnisa, 2004). Spesies tersebut merupakan jenis kepiting bakau yang sering ditemukan di Indonesia (Rizaldi et al., 2015; Sunarto et al., 2015; Widigdo et al., 2017).

Pada Stasiun I dan Stasiun II tidak ditemukan kepiting bakau. Hal ini disebabkan karena pada lokasi tersebut kurang mendapat pasokan air sehingga kondisi substrat menjadi kering. Keberadaan dan kelimpahan kepiting bakau sangat dipengaruhi oleh faktor lingkungan antara lain jenis substrat dan pasang surut. Jenis substrat merupakan faktor pembatas yang dapat mempengaruhi kelimpahan kepiting bakau (Romimohtarto, 2009). Substrat lempung berdebu merupakan habitat yang cocok karena mudah digali dalam mendukung kehidupan kepiting bakau tersebut untuk membenamkan diri, bersembunyi dari predator, melakukan perkawinan, dan pergantian kulit (Prianto, 2007). Selain itu, kepiting bakau tidak menyukai jenis substrat yang kasar dan keras (Setiawan dan Triyanto, 2012). Keberadaan kepiting bakau juga dipengaruhi oleh pasang surut (Supardjo, 2008). Hal ini disebabkan karena kepiting bakau keluar masuk habitat mangrove bersamaan dengan arus dan pasang surut (Siringoringo et al., 2007).

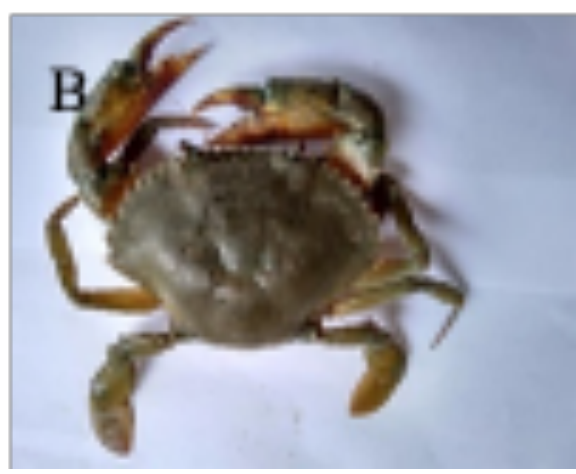

Pada stasiun III (zona dekat dengan muara sungai) ditemukan kepiting bakau dengan jumlah yang bervariasi di setiap plot pengambilan sampel. Lokasi ini memiliki vegetasi mangrove yang didominasi Avicennia marina kategori pohon dengan tingkat kerapatan 560 pohon/ha (Nursofiati et al., 2020). Serasah daun mangrove yang ada di perairan tersebut dimanfaatkan oleh kepiting bakau sebagai sumber nutrisi yang dapat mendukung kehidupan. Selain itu, lokasi stasiun III yang dekat dengan muara sungai menjadi habitat yang cocok untuk kehidupan dan persebaran kepiting bakau.

\subsection{Kelimpahan jenis kepiting bakau}

Pada setiap stasiun pengamatan di kawasan konservasi mangrove Kuala Kota Singkawang memiliki kepadatan jenis kepiting bakau yang berbeda. Pada stasiun I dan stasiun II tidak ditemukan spesies kepiting bakau yang disebabkan oleh tertutupnya aliran air laut dan sungai, juga terdapat banyak sampah. Selain itu, adanya pembangunan ekowisata dapat menyebabkan substrat mengeras dan tidak cocok untuk mendukung kehidupan kepiting bakau. Sejalan dengan Walton et al., (2006),

Tabel 3. Komposisi jenis kepiting bakau di Kuala Kota Singkawang

\begin{tabular}{ccccccccccc}
\hline Spesies & \multicolumn{1}{c}{ St I } & \multicolumn{3}{c}{ St II } & \multicolumn{2}{c}{ St III } \\
\cline { 2 - 10 } & 1 & 2 & 3 & 1 & 2 & 1 & 2 & 3 & 4 \\
\hline S. serrata & 0 & 0 & 0 & 0 & 0 & 2 & 3 & 2 & 2 \\
S. olivacea & 0 & 0 & 0 & 0 & 0 & 0 & 0 & 1 & 1 \\
\hline Total & 0 & 0 & 0 & 0 & 0 & 2 & 3 & 3 & 3 \\
\hline
\end{tabular}


Jurnal Laut Khatulistiwa, Vol. 4. No. 1 (Febuari, 2021), Hal. 7-9.

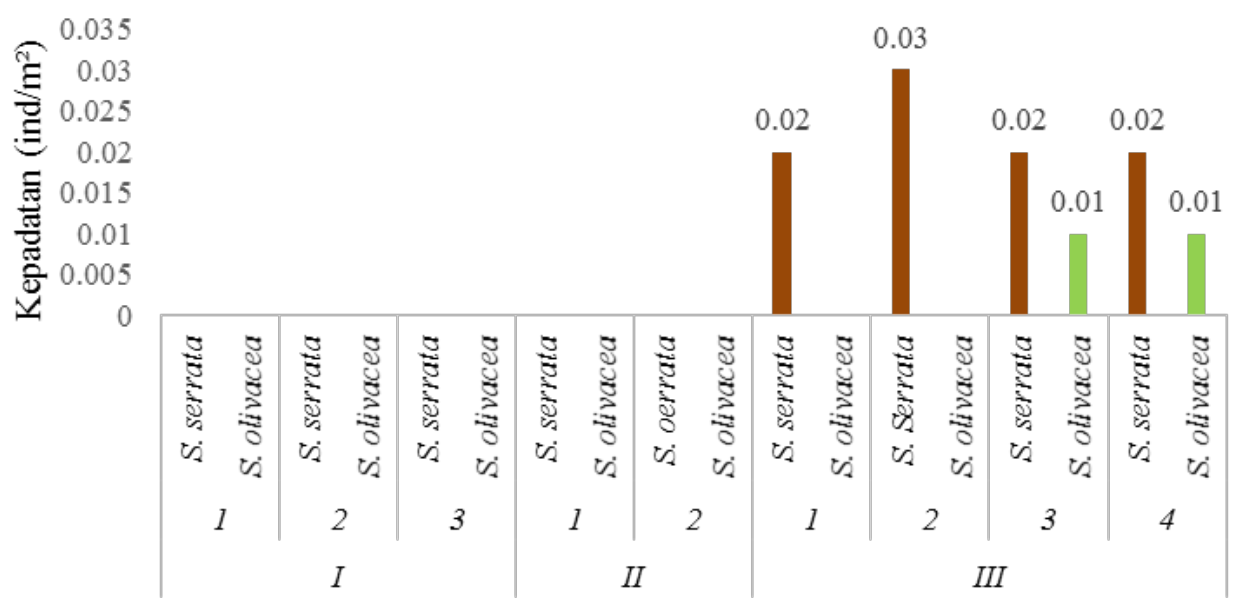

Gambar 4. Kelimpahan jenis kepiting bakau di Kuala Kota Singkawang

kepiting bakau terdistribusi secara luas di area mangrove yang didominasi oleh substrat lumpur. Substrat yang halus di ekosistem mangrove banyak mengandung serasah dan bahan organik. Daun mangrove yang gugur akan terdekomposisi oleh bakteri sehingga menjadi bahan makanan bagi organisme yang ada, termasuk kepiting bakau tersebut. (Avianto, 2013; Soviana, 2004).

Stasiun 3 memiliki kepadatan kepiting bakau sebesar $\left(0,11\right.$ ind $\left./ \mathrm{m}^{2}\right)$ dengan kepadatan masing-masing spesies $S$. serrata $\left(0,09 \mathrm{ind} / \mathrm{m}^{2}\right)$ dan $S$. olivacea $\left(0,02 \mathrm{ind} / \mathrm{m}^{2}\right)$ (Gambar 4). Hal ini disebabkan karena pada stasiun tersebut memiliki tingkat kepadatan mangrove yang tinggi.

Menurut Nursofiati et al., (2020) lokasi tersebut memiliki vegetasi mangrove dengan tingkat kerapatan didominasi Avicennia marina (560 pohon/ha) dan A. lanata (280 pohon/ha) kategori pohon. Selain itu, jenis substrat lempung berdebu dan lokasi yang dekat dengan muara sungai merupakan habitat yang cocok dan dapat mendukung kehidupan kepiting bakau secara optimal serta menjamin kelangsungan proses reproduksi dan ketersediaan makanan alami (Gita et al., 2015).

\subsection{Indeks \\ keanekaragaman, keseragaman dan dominansi}

Indeks keanekaragaman ( $\left.\mathrm{H}^{\prime}\right)$ kepiting bakau di Kawasan Mangrove Kuala Kota Singkawang tergolong dalam kategori rendah. Nilai $\mathrm{H}^{\prime}$ tersebut dapat menggambarkan kelimpahan kepiting bakau yang ada. Nilai indeks keanekaragaman akan tinggi apabila suatu komunitas memiliki jumlah spesies yang banyak dan tiap jenis terwakili oleh individu, sebaliknya indeks keanekaragaman rendah apabila suatu komunitas jumlah jenis yang sedikit dan tiap jenis tersebut memiliki jumlah individu yang banyak.

Indeks keseragaman (E) menunjukan sebaran kepiting bakau dalam suatu komunitas. Perairan di Kuala Kota Singkawang memiliki nilai indeks 0,68 dan masuk dalam kategori keseragaman tinggi. Semakin tinggi nilai indeks keseragaman berarti sebaran individu setiap spesies tersebut sama dan tidak ada spesies yang mendominasi. Tingginya indeks keseragaman pada stasiun 3

Tabel 4. Komposisi jenis kepiting bakau di Kuala Kota Singkawang

\begin{tabular}{crcc}
\hline Indeks & Stasiun I & Stasiun II & Stasiun III \\
\hline $\mathrm{H}^{\prime}$ & - & - & 0,47 \\
$\mathrm{E}$ & - & - & 0,68 \\
$\mathrm{C}$ & - & - & 0,70 \\
\hline
\end{tabular}


Jurnal Laut Khatulistiwa, Vol. 4. No. 1 (Febuari, 2021), Hal. 7-9.

Tabel 5. Kondisi parameter fisika-kimia lingkungan di Kuala Kota Singkawang

\begin{tabular}{|c|c|c|c|c|c|c|c|c|c|c|}
\hline \multirow[t]{2}{*}{ Parameter } & \multirow[t]{2}{*}{ Waktu } & \multicolumn{3}{|c|}{ Stasiun I } & \multicolumn{2}{|c|}{ Stasiun II } & \multicolumn{4}{|c|}{ Stasiun III } \\
\hline & & 1 & 2 & 3 & 1 & 2 & 1 & 2 & 3 & 4 \\
\hline \multirow{3}{*}{ Suhu $\left({ }^{0} \mathrm{C}\right)$} & pagi & 28.7 & 28.8 & 28.7 & 28.4 & 28.7 & 28.6 & 28.6 & 27.9 & 27 \\
\hline & siang & 30.5 & 30.3 & 30.1 & 30.7 & 31.1 & 31.2 & 31.4 & 30.9 & 31.3 \\
\hline & sore & 29.7 & 30 & 30.6 & 31.4 & 31.5 & 30 & 30.9 & 30.6 & 30.9 \\
\hline \multirow{3}{*}{ Salinitas (\%o) } & pagi & 10.3 & 14.8 & 10.5 & 8.8 & 12.7 & 12.6 & 9.3 & 11.5 & 12 \\
\hline & siang & 10.4 & 16.4 & 10.8 & 12.2 & 12.6 & 13.6 & 17 & 11.8 & 13.9 \\
\hline & sore & 11.6 & 17.4 & 12.3 & 16 & 19.1 & 19.1 & 14.7 & 14 & 15.6 \\
\hline \multirow{3}{*}{$\mathrm{pH}$} & pagi & 8 & 8 & 8.2 & 8.3 & 8 & 8 & 8.1 & 8 & 8.1 \\
\hline & siang & 7.3 & 8.3 & 8.1 & 8 & 8 & 8.1 & 8.1 & 8.1 & 8.2 \\
\hline & sore & 8.1 & 8 & 8 & 7.8 & 8 & 7.9 & 8.1 & 8.1 & 8.2 \\
\hline \multirow{3}{*}{$\mathrm{DO}(\mathrm{mg} / \mathrm{L})$} & pagi & 4.5 & 4.7 & 4.4 & 5.5 & 6.8 & 5.9 & 7.1 & 5 & 5.7 \\
\hline & siang & 6.2 & 5.7 & 4.4 & 5.7 & 5.7 & 5.9 & 3.5 & 4.1 & 4.7 \\
\hline & sore & 4.6 & 5.4 & 4.1 & 2.6 & 4.4 & 3.3 & 3 & 3.2 & 2.5 \\
\hline
\end{tabular}

disebabkan oleh kondisi substrat yang cocok dan dapat mendukung kehidupan kepiting bakau. Substrat lempung berdebu merupakan habitat yang cocok karena mudah digali dalam mendukung kehidupan kepiting bakau tersebut untuk membenamkan diri, bersembunyi dari predator, melakukan perkawinan, dan pergantian kulit (Prianto, 2007). Selain itu, keberadaan jenis kepiting bakau juga dipengaruhi oleh pasang surut (Supardjo, 2008). Hal ini disebabkan karena kepiting bakau keluar masuk habitat mangrove bersamaan dengan arus dan pasang surut (Siringoringo et al., 2007).

Indeks dominansi (C) digunakan untuk melihat ada atau tidaknya spesies yang mendominasi di perairan. Nilai indeks dominansi pada perairan Kuala Kota Singkawang memiliki nilai 0,70 dan tergolong dalam kategori sedang. Hal ini disebabkan karena ditemukan spesies $S$. serrata dengan jumlah lebih banyak ( 9 individu) dibandingkan spesies $S$. olivacea ( 2 individu).

\subsection{Parameter fisika-kimia lingkungan}

Kepiting bakau termasuk dalam hewan yang bersifat poikilotermal, yaitu mempunyai suhu tubuh yang sama dengan suhu lingkungannya (Hastuti et al., 2019). Nilai suhu memiliki rentang antara $27-31,4^{\circ} \mathrm{C}$ dan dikategorikan dalam kondisi yang baik untuk pertumbuhan kepiting bakau. Shelley and Lovatelli (2011) menyatakan bahwa suhu optimal untuk menunjang pertumbuhan kepiting bakau berada pada kisaran $25-35^{\circ} \mathrm{C}$.
Suhu ekosistem mangrove yang tidak sesuai dapat juga mengganggu proses fisiologis kepiting bakau, perubahan suhu yang sangat drastis juga akan membuat kepiting bakau menjadi stres yang dapat menimbulkan kematian (Kordi, 2012).

Salinitas merupakan salah satu faktor lingkungan yang berpengaruh penting pada konsumsi pakan, metabolisme, dan pertumbuhan organisme akuatik (Karim, 2005). Hasil pengukuran salinitas memiliki nilai yang bervariasi di setiap stasiun dengan kisaran 8,8-19,1\%o dan tergolong baik untuk pertumbuhan kepiting bakau. Ruscoe et al. (2014) menyatakan bahwa pertumbuhan terbaik kepiting bakau berada pada kisaran 10-20 \%o. La Sara et al. (2014) menyatakan bahwa kepiting bakau dapat menoleransi salinitas pada kisaran 2-40 \%o.

Hasil pengukuran $\mathrm{pH}$ berkisar antara 7,38,3 dan termasuk dalam batasan normal untuk kepiting bakau. Perairan dengan pH 6,50-7,50 dikategorikan perairan yang cukup baik bagi kepiting bakau (Scylla spp.), sedangkan perairan dengan $\mathrm{pH}$ 7,50-9 dikategorikan sangat baik untuk kepiting bakau (Christensen et al., 2005; Romano and Zeng, 2007; Shelley and Lovatelli, 2011). Nilai pH optimum untuk larva kepiting bakau berkisar antara 7-8,5 (Christensen et al., 2005; Hastuti, 2016).

Hasil pengukuran kadar oksigen terlarut (DO) berkisar antara 2,5-7,1 mg/L. Secara umum, kepiting bakau dapat hidup dengan kadar DO kisaran 2-4 mg/L (Christensen et al., 2005), dengan kebutuhan DO minimum yaitu 
Jurnal Laut Khatulistiwa, Vol. 4. No. 1 (Febuari, 2021), Hal. 7-9.

4,00 $\mathrm{mg} / \mathrm{L}$ dan untuk pertumbuhan yang baik yaitu $>5 \mathrm{mg} / \mathrm{L}$ (Mwaluma, 2002). Secara umum, apabila kandungan DO rendah $(<3$ $\mathrm{mg} / \mathrm{L}$ ) akan menyebabkan nafsu makan rendah (Akbar et al., 2016). Hasil pengukuran oksigen terlarut (DO) di Kawasan mangrove Kuala Kota Singkawang masih dalam kategori yang baik untuk mendukung pertumbuhan kepiting bakau. Fujaya (2008) menyatakan konsentrasi oksigen terlarut yang baik untuk kepiting bakau berkisar antara 3-8 mg/L.

Hasil dari pengukuran substrat pada setiap stasiun memiliki tekstur substrat lempung berdebu. Menurut Setiawan dan Triyanto (2012) tekstur substrat yang halus seperti lempung berdebu disukai oleh kepiting bakau sebagai habitatnya, selain itu kepiting bakau juga menyukai habitat yang sedang namun tidak menyukai substrat yang kasar. Substrat lempung berdebu masuk dalam kategori mudah digali oleh kepiting bakau yang digunakan untuk membenamkan diri atau bersembunyi dari predator selama air surut.

Hasil pengukuran pasang surut di kawasan mangrove Kuala Kota Singkawang didapatkan hasil pasang paling tinggi terjadi pada pukul 11.00 WIB dengan ketinggian $85 \mathrm{~cm}$ dan surut paling rendah pada pukul 17.00 WIB dengan ketinggian $41 \mathrm{~cm}$. Keadaan habitat akan mempengaruhi daya adaptasi kepiting bakau (Gita et al., 2015). Selain itu, tinggi rendah pasang surut akan berpengaruh pada kelimpahan kepiting bakau, karena kepiting bakau keluar masuk habitat mangrove bersamaan dengan arus pasang dan surut (Siringoringo et al., 2007).

\section{Kesimpulan}

Kesimpulan dalam penelitian ini adalah :

1. Kepiting bakau yang ditemukan di ekosistem mangrove Kuala Kota Singkawang Kalimantan Barat terdiri dari 2 spesies, yaitu Scylla serrata dan S. olivacea dengan kelimpahan $0,09 \mathrm{ind} / \mathrm{m}^{2}$ dan 0,02 ind $/ \mathrm{m}^{2}$.

2. Kepiting bakau di ekosistem mangrove Kuala Kota Singkawang memiliki indeks keanekaragaman rendah, keseragaman tinggi, dan dominansi sedang.

3. Faktor fisika-kimia perairan di Kawasan mangrove Kuala Kota Singkawang masuk dalam rentang optimal yang dapat mempengaruhi keberadaan dan kelimpahan kepiting bakau.

\section{Saran}

Keanekaragaman dan distribusi kepiting bakau di Kuala Kota Singkawang masih dalam kategori rendah. Oleh karena itu, perlu dilakukan penelitian lebih lanjut mengenai pengaruh aktivitas manusia terhadap pertumbuhan kepiting bakau di ekosistem mangrove dan pengaruh kandungan bahan organik di hutan mangrove sebagai bahan makanan alami kepiting bakau selain guguran serasah di Kuala Kota Singkawang, Kalimantan Barat.

\section{Daftar Pustaka}

Akbar, W., Yusnaini, W.H. Muskita. 2016. Pertumbuhan Kepiting Bakau (Scylla Serrata) yang diberi Pakan Usus Ayam yang dikukus dan Ikan Rucah. Media Akuatika. 1(3): 190-196.

Ashton, E. C., D. J. Macintosh, and P.J. Hogarth. 2003. A baseline study of the diversity and community ecology of Arab and molluscan macrofauna in the Sematan mangrove forest, Sarawak, Malaysia. Journal of Tropical Ecology. 19:127-142.

Avianto, I., S. Sulistiono, dan I. Setyobudiandi. 2013. Karakteristik Habitat dan Potensi Kepiting Bakau (Scylla serrata, S. transquaberica, dan S. olivacea) di Hutan Mangrove Cibako, Sancang, Kabupaten Garut Jawa Barat. Bonorowo Wetlands. 3(2): 55-72.

Badan Pusat Statistik Kota Singkawang. 2016. Singkawang dalam Angka.

Brower, J. E. dan J. H. Zar. 1989. Field and Laboratory Methods for General Ecology. W.M. Brown Company Publ. Dubuque Lowa.

Chairunnisa, R. 2004. Kelimpahan Kepiting Bakau (Scylla sp.) di Kawasan Hutan Mangrove KPH Batu Ampar, Kabupaten Pontianak, Kalimantan Barat. Skripsi. Bogor: Prodi Ilmu Kelautan, Departemen Ilmu dan Teknologi Kelautan, Fakultas Perikanan dan Ilmu Kelautan, Institut Pertanian Bogor.

Christensen, S. M., D. J. Macintosh, dan P. T. Nguyen. 2005. Pond production of the mud crabs Scylla paramamosain 
Jurnal Laut Khatulistiwa, Vol. 4. No. 1 (Febuari, 2021), Hal. 7-9.

(Estampador) and S. olivacea (Herbst) in the Mekong Delta, Vietnam, using two different supplementary diet. Aquaculture Research. 35(11):10131024.

Fujaya, Y. 2008. Kepiting Komersil di Dunia, Biologi, Pemanfaatan, dan Pengelolaannya. Citra Emulsi. Makasar.

Gita, R. S. D., J. Sudarmadji, Waluyo. 2015, Pengaruh Abiotik terhadap Keanekaragaman dan Kelimpahan Kepiting Bakau (Scylla spp.) di Hutan Mangrove Taman Nasional Alas Purwo, Jawa Timur. Bonorowo Wetlands. 5(1): 11-20.

Hastuti, Y. P., H. Nadeak, R. Affandi, K. Faturrohman. 2016. Optimum pH Determination for Mangrove Crab Scylla Serrata Growth in Controlled Containers. J.urnal Akuakultur Indonesia. 15:24-37.

Karim, M. Y. 2005. Kinerja Pertumbuhan Kepiting Bakau Betina (Scylla Serrata Forskal) pada berbagai Salinitas Media dan Evaluasinya pada Salinitas Optimum dengan Kadar Protein Berbeda. Disertasi. Bogor : Program Pascasarjana, Institut Pertanian Bogor.

Kementrian Kelautan Perikanan. 2016, Tentang Pedoman Pemeriksaan/ Identifikasi Jenis Ikan dilarang Terbatas. Jakarta.

Kordi, K. 2012. Ekosistem Mangrove, Potensi, Fungsi dan Pengelolaan. Jakarta: Rineka Cipta. 256 hlm.

La Sara, Aguilar, R.O., Ingles, J.A., Laureta, L.V., 2014, Habitat characteristics and relative abundance of the mud crab Scylla serrata (Forskål, 1775) in Lawele Bay, Southeast Sulawesi, Indonesia, Ege J Fish Aqua Sci, 31(1): 11-18.

Macintosha, D. J., E. C. Ashtona., S. Havanon. 2002. Mangrove Rehabilitation and Intertidal Biodiversity: a Study in the Ranong Mangrove Ecosystem, Thailand. Estuarine, Coastal and Shelf Science, 55: 331-345

Mwaluma, J. 2002. Pen Culture of the Mud Crab Scylla serrata in Mtwapa Mangrove System, Kenya, Western Indian Ocean journal of Marine Science, 1(2): 127-133.

Nagelkerken, I., S. J. M. Blaber, S., Bouillon, P. Green., M. Haywood,, L. G. Kirton,. J.O. Meynecke, J. Pawlik, H. M. Penrose, H. A.
Sasekumar., P.J. Somerfield. 2008, The Habitat Function of Mangroves for Terrestrial and Marine Fauna: A Review. Aquatic Botany, 89(2): 155-185.

Nursofiati., A.A. Kushadiwijayanto, dan I. Safitri. 2020, Struktur Komunitas dan Laju Produksi Karbon Serasah Daun Mangrove di Kuala Singkawang. Jurnal Laut Khatulistiwa, 3(3): 105-112.

Odum, E. P. 1993. Dasar-Dasar Ekologi. Diterjemahkan dari Fundamental of Ecology oleh T. Samingan. Gadjah Mada University Press. Yogyakarta.

Prianto, E. 2007. Peran Kepiting sebagai Spesies Kunci (Keystone Spesies) pada Ekosistem Mangrove. Prosiding Forum Perairan Umum Indonesia IV. Banyuasin: Balai Riset Perikanan Perairan Umum.

Rahayu, L. D. dan G. Setyadi. 2009. Mangrove Estuary Crabs of The Mimika Region, Papua, Indonesia, PT. Freeport Press, Mimika-Papua.

Rangkuti, A.M., M.R., Cordova, A. Rahmawati, Yulma, dan Adimu, H.E., 2017, Ekosistem Pesisir dan Laut Indonesia. Jakarta: Bumi Aksara.

Riniatsih dan E.W. Kushartono. 2009, Substrat Dasar dan Parameter Oseanografi Sebagai Penentu Keberadaan Gastropoda dan Bivalvia di Pantai Sluke Kabupaten Rembang, Ilmu Kelautan, 14(1): 50-59.

Rizaldi, D. Rosalina,. dan E. Utami. 2015. Kelimpahan Kepiting Bakau (Scylla sp.) di Perairan Muara Tebo Sungailiat, Akuatik, 9(2): 14-20.

Romano, N dan C. Zeng. 2007, Acute toxicity of ammonia and its effects on the haemolymph osmolality, ammonia- $\mathrm{N}, \mathrm{pH}$ and ionic composition of early juvenile mud crabs, Scylla serrata (Forskal), Molecular \& Integrative Physiology, 148(2): 278-285.

Romimohtarto, K. dan S. Juwana. 2001. Biologi Laut: Ilmu Pengetahuan tentang Biota Laut. Puslitbang Oseanologi LIPI. Jakarta. $527 \mathrm{hlm}$.

Ruscoe I. M., C.C. Shelley, , G.R. Williams. 2004. The combined effects of temperature and salinity on growth and survival of juvenile mud crabs (Scylla serrata Forsskal). Aquaculture, 238: 239-247. 
Jurnal Laut Khatulistiwa, Vol. 4. No. 1 (Febuari, 2021), Hal. 7-9.

Setiawan, F. dan Triyanto. 2012. Studi Kesesuaian Lahan untuk Pengembangan Silvofishery Kepiting Bakau (Scylla Serrata) di Kabupaten Berau, Kalimantan Timur. LIMNOTEK, 19(2): 158-165.

Shelley, C. dan A. Lovatelli. 2011. Mud crab aquaculture a practical manual. FAO Fisheries and Aquaculture Technical Paper. 78p.

Siringoringo, Y.N., Desrita, Yunasfi, 2017, Kelimpahan dan pola pertumbuhan kepiting bakau (Scylla serrata) di hutan mangrove Kelurahan Belawan Sicanang, Kecamatan Medan Belawan, Provinsi Sumatera Utara. Acta Aquatica, 4(1): 2632.

Soviana, W. 2004, Hubungan Kerapatan Mangrove terhadap Kelimpahan Kepiting Bakau di Teluk Buo, Kecamatan Bungus Teluk Kabung, Padang Sumatra Barat. Fakultas Perikanan dan Ilmu Kelautan, Institut Pertanian Bogor.

Sunarto, Sulistiono, I. Setyobudiandi. 2015. Hubungan Jenis Kepiting Bakau (Scylla spp.) dengan Mangrove dan Substrat di Tambak Silvofishery Eretan, Indramayu. Marine Fisheries. 6(1): 59-68.

Supardjo, M. N. 2008. Identifikasi Vegetasi Mangrove di Segoro Anak Selatan, Taman Nasional Alas Purwo Banyuwangi, Jawa Timur. Jurnal Perikanan. 3(2): 9-15.

Widigdo, B., Rukisah, A. Laga, A.A. Hakim, Y. Wardiatno. 2017. Carapace lengthweight and width-weight relationships of Scylla serrata in Bulungan District, North Kalimantan, Indonesia. Biodiversitas. 18(4):1316-1323.

Walton, M.E., L. Le Vay, J. H. Lebata, J. Binas, J.H. Primavera. 2006. Seasonal abundance, distribution and recruitment of mud crabs (Scylla sp.) in replanted mangroves. Estuarine Coastal and Shelf Science. 66(3): 493-500.

Widyastuti, E. 2016. Keanekaragaman Kepiting pada Ekosistem Mangrove di Perairan Lingga Utara dan Sekitarnya, Kepulauan Riau. Zoo Indonesia, 25(1): 22-32.

Yulianti dan M.J.S. Sofiana. 2018. Kelimpahan Kepiting Bakau (Scylla sp) di Kawasan Rehabilitasi Mangrove Setapuk
Singkawang. Jurnal Laut Khatulistiwa. 1(1): 25-30. 